\title{
Social media as an open-learning resource in medical education: current perspectives
}

This article was published in the following Dove Press journal:

Advances in Medical Education and Practice

8 June 2017

Number of times this article has been viewed

\author{
S Sutherland' \\ A Jalali ${ }^{2}$ \\ 'Department of Critical Care, \\ The Ottawa Hospital, ${ }^{2}$ Division \\ of Clinical and Functional Anatomy, \\ Faculty of Medicine, University \\ of Ottawa, Ottawa, ON, Canada
}

Purpose: Numerous studies evaluate the use of social media as an open-learning resource in education, but there is a little published knowledge of empirical evidence that such open-learning resources produce educative outcomes, particularly with regard to student performance. This study undertook a systematic review of the published literature in medical education to determine the state of the evidence as to empirical studies that conduct an evaluation or research regarding social media and open-learning resources.

Methods: The authors searched MEDLINE, ERIC, Embase, PubMed, Scopus, and Google Scholar from 2012 to 2017 . This search included using keywords related to social media, medical education, research, and evaluation, while restricting the search to peer reviewed, English language articles only. To meet inclusion criteria, manuscripts had to employ evaluative methods and undertake empirical research.

Results: Empirical work designed to evaluate the impact of social media as an open-learning resource in medical education is limited as only 13 studies met inclusion criteria. The majority of these studies used undergraduate medical education as the backdrop to investigate open-learning resources, such as Facebook, Twitter, and YouTube. YouTube appears to have little educational value due to the unsupervised nature of content added on a daily basis. Overall, extant reviews have demonstrated that we know a considerable amount about social media use, although to date, its impacts remain unclear.

Conclusion: There is a paucity of outcome-based, empirical studies assessing the impact of social media in medical education. The few empirical studies identified tend to focus on evaluating the affective outcomes of social media and medical education as opposed to understanding any linkages between social media and performance outcomes. Given the potential for social media use in medical education, more empirical evaluative studies are required to determine educational value.

Keywords: social media, Facebook, YouTube, medical education, evaluation

\section{Introduction}

Social media has become an integral tool for medical societies, hospitals, and advocacy groups. These groups are using social media to engage, teach, and connect, and they play an important role in providing accurate, vetted health information. In addition, organizations have realized that encouraging live-tweeting or blogging of conferences provides opportunities for wide dissemination of content. ${ }^{1-3}$ Medicine and health care professions have widely embraced the use of social media in medical education, and there is a growing culture of sharing open resources in medicine
Correspondence: A Jalali Division of Clinical and Functional Anatomy, Faculty of Medicine, University of Ottawa, Ottawa, ON KIH 8M5, Canada $\mathrm{Tel}+\mathrm{I} 6135625800$ ext 5782

Fax + I 6135625687 Email ajalali@uottawa.ca 
with internationally well-established repositories. Research activity is investigating growing numbers of open data sets on health but there seems to be little discussion around how these might effectively be used in medical education. That is, the quality of the content on social media and the Internet is solely dependent on the members of the online community. Although there may be real-time peer-review to critique misleading and/or incorrect information, the quality of that content may be variable. Perhaps most importantly, recent research has demonstrated a lack in high-quality evidence, infrequent assessment of skill or behavior-based outcomes, and no assessment of patientbased outcomes. ${ }^{4-6}$ What we need is to employ structured processes to better understand the impact(s) social media is having on medical education. Free and unregulated information available on the Internet carries the potential hazard of misinformation. ${ }^{7}$

In becoming more "evidence-based," North American medical schools have embraced the necessity and utility of evaluation. Learning from and about evaluation often requires us to change our mental models - to rethink our assumptions and beliefs to develop new understandings about our programs and evaluation processes. Evaluation purposes range from hard-nosed judgement-oriented summative exercises to formative, improvement-oriented ones that tend solely to provide support for decision-making. These evaluations can be conducted by members or groups external to the program and/or organization, by those internal to it, or by a blend of the two. ${ }^{8}$ Multiple methods can be employed in evaluation, ranging from quantitative to qualitative and often involving a mix of the two.

Ultimately, evaluation leads to knowledge production, the validity, credibility, sophistication, timeliness, and relevance of which depend on the evaluation processes in place. It also leads to forms of the use of the knowledge produced. Empirical research and evaluation is based on an observed and measured phenomenon and derives knowledge from actual experience rather than from theory or simply beliefs. ${ }^{9}$ Characteristics of empirical studies include specific research/ evaluation questions to be answered, a definition of the population, behavior, or phenomena being studied, description of the processes used to study this population including selection criteria, and testing instruments (i.e., surveys and interview protocols). This study undertook a systematic review of the published literature in medical education to determine the state of the evidence as to empirical studies that conduct an evaluation or research regarding social media and openlearning resources.

\section{Methods}

\section{Review of current empirical evaluative literature}

In essence, this article represents a form of meta-analysis of empirical research and evaluation in the area. Described below are the sampling criteria, characteristics of the sample, and the method used to analyze findings across studies.

\section{Sampling criteria}

With the abundance of interest in the domain of social media in medical education, the search terms "social media and medical education" generated a plethora of peer-reviewed articles. However, our purpose here is to determine what work has been done in terms of actual empirical research and evaluation of the use of social media in medical education. For this reason, we restricted our sample to the past 5 years (2012-2017). We searched the literature in six popular databases (MEDLINE, ERIC, Embase, PubMed, Scopus, and Google Scholar) for English-language studies on social media use in medical education published in peer-reviewed journals. We followed a similar definitional strategy as used by Cheston et al and defined social media as Web-based technologies that facilitate multi-user interaction that goes beyond fact sharing. ${ }^{4,10,11}$ We defined medical education as all levels of physician training (medical school, residency, fellowship, and continuing medical education). We subsumed any potential patient outcomes within our general search terms of "social media", "medial education", and "evaluation". From the initial sample, we deleted all duplicates as well as clearly irrelevant work. From the initial sample, we tracked down other peer-reviewed studies through bibliographic follow-up. Table 1 illustrates the steps we took in conducting the systematic literature review.

\section{Results}

All of the studies meeting inclusion are listed in Table 2. Each of the studies analyzed their various elements, including research design/data collection methods, study population, medical speciality, open-learning resource tool(s) under evaluation, and study outcomes. Each will be discussed in turn.

\section{Research/evaluation design}

Six studies employed a qualitative design, whereby data were extracted from either Facebook or YouTube then qualitatively analyzed for themes. ${ }^{72-16}$ Four of these studies employed almost the exact same design to investigate the quality and accuracy of material on YouTube. ${ }^{713-15}$ Specifically, a given 
Table I Literature review process

\begin{tabular}{|c|c|}
\hline Step & Description \\
\hline $\begin{array}{l}\text { Identified and } \\
\text { downloaded } \\
\text { documents }\end{array}$ & $\begin{array}{l}\text { Searched the literature for the period of January } \\
\text { I } 2012 \text { to January I, } 2017 \text { in the following } \\
\text { databases: MEDLINE, ERIC, Embase, PubMed, } \\
\text { Scopus, and Google Scholar. Keywords used } \\
\text { in the empirical review included: "social } \\
\text { media", "medical education", and "evaluation". } \\
\text { Found } 406 \text { entries; SS reviewed all entries and } \\
\text { identified I } 28 \text { for further consideration. }\end{array}$ \\
\hline $\begin{array}{l}\text { Inclusion criteria and } \\
\text { selected documents } \\
\text { that met the criteria }\end{array}$ & $\begin{array}{l}\text { Developed and applied inclusion criteria that the } \\
\text { studies had to I) be reported in peer-reviewed } \\
\text { journals, 2) be published within the five-year } \\
\text { time period (20I2-20I7), 3) report on empirical } \\
\text { data with descriptions of study methods, and } \\
\text { 4) authors must be conducting an evaluation } \\
\text { or research regarding social media and open- } \\
\text { learning resources. Identified I } 3 \text { articles that } \\
\text { met inclusion criteria. }\end{array}$ \\
\hline $\begin{array}{l}\text { Identified and coded } \\
\text { appropriate } \\
\text { information; analyzed } \\
\text { the information }\end{array}$ & $\begin{array}{l}\text { Studies were coded for I) research design and } \\
\text { data collection methods, 2) medical speciality, } \\
\text { 3) target population, and 4) study outcomes. }\end{array}$ \\
\hline
\end{tabular}

number of terms were searched on YouTube, videos were downloaded and analyzed for specific domain-specific content. The Camm et al paper employed a "purpose-built tool" to rate the videos. ${ }^{14}$ Alotaibi et al employed a similar design as the studies listed above; however, they widened their search not only to YouTube but also to include Facebook and Twitter. ${ }^{12}$ Only one paper employed a rigorous qualitative design including conducting 10 focus groups with participants. ${ }^{17}$

Four studies used a quantitative design whereby they utilized a survey instrument to obtain perceptual data on social media uses. ${ }^{18-21}$ Of the remaining two studies, one employed a mixed-method design whereby they distributed questionnaires to Twitter users, and then conducted focus groups. ${ }^{21}$ The other study utilized a pre- and post-design..$^{22}$ For example, the authors examined Facebook profiles for the presence of security settings, gave an intervention in the form of a workshop focused on professionalism and social media, and finally re-examined the same Facebook profiles for any evidence of impact from the intervention.

\section{Study population}

Overwhelmingly, the majority of studies $(\mathrm{N}=10)$ were directed to examine open-learning resources for undergraduate medical student use focus on undergraduate medical students' pedagogical preferences, practices, and utilization patterns. One study ${ }^{18}$ focused its inquiry on differences in social media use between medical residents and faculty, whereas another study investigated faculty uses of social media. The final study was interested in a specific segment of a given population, specifically, low socioeconomic status, African Americans in upstate New York. ${ }^{23}$

\section{Medical specialty}

Ultimately, we identified a total sample of 13 studies (Table 1). The most frequently cited speciality was anatomy with three studies. ${ }^{13,15,22}$ Two studies were found within the domain of cardiology. ${ }^{7,14}$ The remaining studies were spread across a variety of medical specialities including pathology, ${ }^{20}$ emergency medicine, ${ }^{18}$ neurosurgery, ${ }^{12}$ and another study focused on continuing medical education. ${ }^{21}$ Of the remaining four studies that met inclusion criteria, three applied to the broad domain of undergraduate medical education. ${ }^{16,19,23}$ The final study was focused on a community health intervention with the authors representing a cancer center. ${ }^{17}$

\section{Open-learning resource tools}

YouTube and Facebook were the most commonly evaluated social media tools. Four studies focused their assessments on the credibility and educational utility of material on YouTube. ${ }^{7,13-15}$ Three studies focused on utilization frequencies and patterns assessed both Facebook and YouTube. 12,19,21 Facebook was the primary social media tool used in three studies. ${ }^{16,20,23}$ Only one study meeting inclusion criteria examined Twitter as an open-learning educational resource. ${ }^{22}$ The final two studies ${ }^{17,18}$ examined social media in a more general way. Pearson et al study was most interested in frequency of social media use between residents and faculty, whereas the Mahoney et al paper focused on social media use in terms of the most effective distribution mechanism. ${ }^{17,18}$

\section{Study outcomes}

Facebook was viewed to have positive effects on the more affective dimensions of learning. That is, studies found Facebook to be useful in promoting collaborative online communities of learners ${ }^{16,20}$ as well as an effective means to distribute content-specific information to key subgroups (i.e., brain aneurysm patients). ${ }^{12}$ Study outcomes were weak as they relied primarily on self-reporting and may not be transferrable to other populations or contexts. The four studies focusing solely on assessing YouTube content were consistent in their consensus that YouTube is often an inadequate source of information for learning medical content. ${ }^{713-15}$

Studies that investigated open resources more broadly, that is, not focusing on a single tool but rather sought to determine the preferred tool among users generally found age and/or technical savviness to be a key component in social 
Table 2 Descriptive characteristics of empirical evaluative studies

\begin{tabular}{|c|c|c|c|c|c|}
\hline Study & Sample & Context & Methods & $\begin{array}{l}\text { Purpose evaluation/ } \\
\text { research question(s) }\end{array}$ & Main findings \\
\hline Alotaibi et al ${ }^{12}$ & $\begin{array}{l}\text { Social media } \\
\text { platforms (Facebook, } \\
\text { Twitter and } \\
\text { YouTube) }\end{array}$ & $\begin{array}{l}\text { Focus on patient } \\
\text { quality of life } \\
\text { and psychosocial } \\
\text { well-being. Use } \\
\text { of social media } \\
\text { for support and } \\
\text { education }\end{array}$ & $\begin{array}{l}\text { Mixed-method. } \\
\text { Data extracted } \\
\text { from social } \\
\text { media platforms } \\
\text { and thematic } \\
\text { analysis on online } \\
\text { communications }\end{array}$ & $\begin{array}{l}\text { Evaluate current } \\
\text { use of social media } \\
\text { communication regarding brain } \\
\text { aneurysms }\end{array}$ & $\begin{array}{l}\text { Facebook is the most widely used } \\
\text { medium among ruptured/un- } \\
\text { ruptured brain aneurysm patients. } \\
\text { Facebook accounts were all } \\
\text { non-profit foundations or patient } \\
\text { support groups. The majority of } \\
\text { users in Facebook were joining } \\
\text { private support groups as opposed } \\
\text { to public }\end{array}$ \\
\hline $\mathrm{Azer}^{13}$ & $\begin{array}{l}235 \text { YouTube videos } \\
\text { identified using search } \\
\text { terms: "surface } \\
\text { anatomy", "anatomy } \\
\text { body painting", "living }\end{array}$ & $\begin{array}{l}\text { Saudi Arabian } \\
\text { medical students } \\
\text { learning of } \\
\text { surface anatomy, } \\
\text { problem- }\end{array}$ & $\begin{array}{l}\text { Search YouTube } \\
\text { with keywords } \\
\text { related to learning } \\
\text { surface anatomy }\end{array}$ & $\begin{array}{l}\text { Assess sample of YouTube } \\
\text { videos covering surface } \\
\text { anatomy }\end{array}$ & $\begin{array}{l}\text { YouTube is an inadequate source } \\
\text { of information for learning surface } \\
\text { anatomy. More work is needed } \\
\text { from medical schools/educators to } \\
\text { add useful videos on YouTube }\end{array}$ \\
\hline
\end{tabular}

anatomy", "bone based learning

landmarks" and environment

"dermatomes"

Camm et al ${ }^{14} \quad$ YouTube queries

related to heart

sound/murmurs/

conditions

$\begin{array}{ll}\text { Hennessy } & \text { Undergraduate } \\ \text { et a }{ }^{22} & \text { medical students, } \\ & \text { Year } 2\end{array}$

Engagement with neuro-anatomy

content, UK, medical school

Educationa

value of

YouTube videos,

undergraduate

medical learning,

UK

Search YouTube with keywords

related to cardiac auscultation

$\sqrt{2}$

Assess the quality of videos relating to heart sounds and murmurs contained on YouTube. Search terms:"heart murmur", "heart sounds", "heart auscultation". Quality was assessed for audiovisual quality, teaching quality, comprehensiveness, and file metrics

Mixed method, survey and focus group

\section{medical school}

\section{Evaluate if Twitter supports} students learning neuroanatomy. Students asked to use hashtag NLM2 and develop it as they preferred. Conducted post module analysis of hashtag use

$\begin{array}{clll}\text { Mahoney et al }{ }^{17} & \text { Low socio-economic } & \text { Research on } & \text { Qualitative, ten } \\ \text { status, African } & \text { social media, focus groups } \\ & \begin{array}{l}\text { Americans, stratified } \\ \text { by age group. }\end{array} & \text { smoking cessation } & \\ & \text { Strategies in } & \\ \text { Recruited from } & \text { upstate New } & \\ \text { urban primary care } & \text { York (Buffalo and } \\ \text { medical offices } & \text { Niagara Falls) }\end{array}$

Pant et $\mathrm{al}^{7} \quad$ YouTube queries related to acute myocardial infarction

\section{Educational accuracy and} credibility of YouTube videos, US undergraduate medical students

Pearson et al ${ }^{18} \quad$ Emergency medicine residents and faculty, US medical school

Emergency medicine use of social media in academic medical centers
Search YouTube with keywords related to myocardia infarction inferion

Quantitative 18 question email survey
Investigate patient perceptions of smoking cessation strategies via social media (e.g., Facebook, instant messaging, texting, cell phone to access social media)

Assess the credibility of YouTube video information on acute myocardial infarction by exploring the relationship between accuracy of information on the topic, source of expertise, and perceived credibility of the message Assess patterns of social media use for personal and professional purposes among emergency medicine residents and faculty
The quality of videos found was highly variable. YouTube indications of preference were of no value in determining video content. Teaching institutions/professional societies should endeavor to identify and highlight good online teaching resources

Negligible correlation between Twitter engagement and exam performance, suggesting that the use of Twitter in this context is limited to enhancing the student experience rather than improving knowledge

There exist variation in preferences for smoking cessation support among younger and older patients. Younger patients preferred to use Facebook and texts, older patients preferred pre-recorded messages from their doctors to their cell phones

The information on the YouTube platform is not regulated and can easily mislead those seeking it. Authoritative videos should come from reputable sources such as professional societies and/or academic institutions

Emergency medicine residents and faculty have different patterns and interests in their personal and professional uses of social media. Overall, residents used social media sites more frequently than faculty, notably in daily personal use 
Table 2 (Continued)

\begin{tabular}{|c|c|c|c|c|c|}
\hline$\overline{\text { Study }}$ & Sample & Context & Methods & $\begin{array}{l}\text { Purpose evaluation/research } \\
\text { question(s) }\end{array}$ & Main findings \\
\hline $\begin{array}{l}\text { Raikos and } \\
\text { Waidyasekara }^{15}\end{array}$ & $\begin{array}{l}\text { Undergraduate } \\
\text { medical students }\end{array}$ & $\begin{array}{l}\text { Assess quality } \\
\text { and quantity of } \\
\text { educational videos } \\
\text { (via YouTube), } \\
\text { Australian student } \\
\text { learning }\end{array}$ & Mixed method & $\begin{array}{l}\text { Assess availability and } \\
\text { usefulness of YouTube for } \\
\text { learning heart anatomy. } \\
\text { Developed scoring system to } \\
\text { include: Anatomical Content } \\
\text { Score (ACS), General Quality } \\
\text { Score (GQS), and General } \\
\text { Data (GD) }\end{array}$ & $\begin{array}{l}\text { Difficult to determine high } \\
\text { educational value. Most cadaveric } \\
\text { videos were recorded by students } \\
\text { using their portable mobile devices, } \\
\text { thus a poor cinematography and } \\
\text { image quality was observed. This } \\
\text { reflected a poor mean GQS of } \\
\text { cadaver videos }\end{array}$ \\
\hline $\begin{array}{l}\text { Strausburg } \\
\text { et al }{ }^{19}\end{array}$ & $\begin{array}{l}618 \text { third and fourth } \\
\text { year undergraduate } \\
\text { medical students, } \\
\text { Indiana University } \\
\text { School of Medicine }\end{array}$ & $\begin{array}{l}\text { US residency } \\
\text { application } \\
\text { processes, } \\
\text { undergraduate } \\
\text { medical schools }\end{array}$ & $\begin{array}{l}\text { Quantitative email } \\
\text { survey }\end{array}$ & $\begin{array}{l}\text { Evaluate medical students' } \\
\text { behavior regarding online } \\
\text { social networks in preparing } \\
\text { for the residency matching } \\
\text { process }\end{array}$ & $\begin{array}{l}\text { The majority of students planned to } \\
\text { (or did) alter their online profiles } \\
\text { in preparation for the residency } \\
\text { match process. This study implies } \\
\text { that the more medical students } \\
\text { perceive that residency directors } \\
\text { use social media in application } \\
\text { screening processes, the more they } \\
\text { will alter their online profiles to } \\
\text { adapt to protect their professional } \\
\text { persona }\end{array}$ \\
\hline $\begin{array}{l}\text { Thalluri and } \\
\text { Penman }{ }^{20}\end{array}$ & $\begin{array}{l}\text { First and second } \\
\text { year medical } \\
\text { radiation students, } \\
\text { and second year } \\
\text { nursing students }\end{array}$ & $\begin{array}{l}\text { Pathology and } \\
\text { clinical sciences } \\
\text { learning, } \\
\text { Australian medical } \\
\text { school }\end{array}$ & $\begin{array}{l}\text { Engaged students } \\
\text { in Facebook } \\
\text { activity, then } \\
\text { conducted post- } \\
\text { intervention } \\
\text { questionnaire }\end{array}$ & $\begin{array}{l}\text { Investigate the success of } \\
\text { Facebook as an educational } \\
\text { tool for a pathology course for } \\
\text { medical students and a clinical } \\
\text { sciences course for nursing } \\
\text { students }\end{array}$ & $\begin{array}{l}\text { Both student cohorts found the } \\
\text { use of Facebook beneficial in } \\
\text { terms of providing an innovative } \\
\text { way of learning, fostering greater } \\
\text { interaction amongst co-students } \\
\text { and staff, and effectively engaging } \\
\text { them with the content of courses }\end{array}$ \\
\hline Wang et $\mathrm{al}^{21}$ & $\begin{array}{l}539 \text { Mayo Clinic } \\
\text { Internal Medicine } \\
\text { CME Participants }\end{array}$ & $\begin{array}{l}\text { US continuing } \\
\text { medical education, } \\
\text { internal medicine } \\
\text { physicians }\end{array}$ & $\begin{array}{l}\text { Quantitative } \\
\text { cross-sectional } \\
\text { survey }\end{array}$ & $\begin{array}{l}\text { Determine CME course } \\
\text { participants' use of social } \\
\text { media and their attitudes about } \\
\text { the value of social media for } \\
\text { enhancing CME education }\end{array}$ & $\begin{array}{l}\text { Most respondents reported using } \\
\text { social media, with YouTube and } \\
\text { Facebook as the most common } \\
\text { types. More favourable attitudes } \\
\text { towards social media were found } \\
\text { with the younger ages. Study } \\
\text { suggests CME directors should } \\
\text { guide social media strategies } \\
\text { toward more youthful, technology } \\
\text { savvy CME participants }\end{array}$ \\
\hline Walton et $\mathrm{al}^{23}$ & $\begin{array}{l}\text { I52 third and fourth } \\
\text { year undergraduate } \\
\text { medical students }\end{array}$ & $\begin{array}{l}\text { Alberta, Canada } \\
\text { medical school }\end{array}$ & $\begin{array}{l}\text { 3-Intervention } \\
\text { phase study } \\
\text { (review student } \\
\text { Facebook profiles, } \\
\text { give lecture on } \\
\text { professionalism, } \\
\text { evaluate profiles } \\
\text { for altered privacy } \\
\text { settings }\end{array}$ & $\begin{array}{l}\text { Examine the Internet presence } \\
\text { of a graduating medical school } \\
\text { class by scanning students' } \\
\text { public Facebook profiles, and } \\
\text { incorporating this data into an } \\
\text { educational activity addressing } \\
\text { professionalism and social } \\
\text { media, then evaluate the } \\
\text { impact of the activity on student } \\
\text { behavior }\end{array}$ & $\begin{array}{l}\text { A small but significant portion } \\
\text { of students share potentially } \\
\text { unprofessional content on social } \\
\text { media. An interactive educational } \\
\text { intervention, which includes specific } \\
\text { disclosure of how participants } \\
\text { appear to others on social media } \\
\text { resulted in significant change in } \\
\text { student behavior }\end{array}$ \\
\hline $\begin{array}{l}\text { Whittaker } \\
\text { et al }{ }^{16}\end{array}$ & $\begin{array}{l}\text { Undergraduate } \\
\text { science students }\end{array}$ & $\begin{array}{l}\text { Online learning } \\
\text { communities of } \\
\text { practice, within } \\
\text { cohort study }\end{array}$ & $\begin{array}{l}\text { Qualitative } \\
\text { assessment of } \\
\text { Facebook posts }\end{array}$ & $\begin{array}{l}\text { Explore the success of } \\
\text { Facebook as a tool for } \\
\text { the formation of an online } \\
\text { community }\end{array}$ & $\begin{array}{l}\text { Facebook is viewed as a promising } \\
\text { tool to establish an online } \\
\text { educational community, particularly } \\
\text { for undergraduate science students }\end{array}$ \\
\hline
\end{tabular}

Abbreviation: CME, continuing medical education.

media use. Pearson et al found that residents were far more likely to utilize social media than were faculty. ${ }^{18}$ Similarly, Wang et al found younger faculty (and those technologically inclined) more likely to use social media with regard to continuing medical education. ${ }^{21}$ Perhaps, the most rigorous of all the studies that met inclusion criteria ${ }^{22}$ demonstrated a negligible correlation between medical students, Twitter engagement and exam performance suggesting that the use of Twitter in this context is limited to enhancing the student experience rather than improving knowledge. 


\section{Discussion}

The growing integration of social media into medical education has led some to believe that social media constitutes the cornerstone platform for the future of medical education. Perhaps for this reason and despite a decade of social media presence, scores of studies are still probing the utilization question. That is, many peer-reviewed papers are commentary in nature seeking to describe potential uses of social media in medical education. This study has demonstrated the paucity of research and evaluative work that is employing methods for deeper understanding as to the potential impacts of social media in medical education. The limited number of empirical studies should not be taken to mean that social media as open-source learning has not received much attention in the literature. On the contrary, there are numerous studies on the topic; however, most are commentaries and/or reflective narratives that were not included in this study.

Open-learning resources (integrate Facebook, YouTube, and Twitter) have no correlation with student performance, rather there was only a correlation with student affect. Facebook appeared to have an impact in terms of creating online-learning communities and fostering-increased learner engagement in educational content. True value may be to enhance the student experience rather than with the explicit aim of improving exam performance. YouTube was found to be an inadequate resource for educational purposes due to the highly variable content. The modern world has censorshipfree access to the internet that requires a high degree of responsibility for those making educational material available to the public. ${ }^{15}$ A novel service named YouTube EDU has been introduced recently giving access to a broad set of academic lectures and inspirational speeches endorsed by institutions and universities and has replaced the previous education category. ${ }^{24}$ Some studies located called for YouTube to institute a moderating service so as to assess the quality of educational videos, though many authors noted that this was likely not a practical suggestion given the volume of new content that is added to YouTube on a daily basis., ${ }^{714}$

Perhaps, social media as an open-learning resource in medical education is geared for the young and the young at heart. The majority of studies included in this study served to better understand learning at the undergraduate medical student level. Furthermore, some study outcomes explicitly found social media use more prevalent in younger students, and those labeled "youthful" and "technologically savvy." ${ }^{18}$ More empirical evaluative work needs to be directed to better understand the linkage between social media use and generational differences. We know a considerable amount about social media use, although to date, its impacts remain unclear. Despite the existence of social media platforms for more than a decade, the vast majority of peer-reviewed studies in the literature do not engage in rigorous programmatic evaluation.

\section{Limitations}

This study has several limitations. Despite making every attempt to capture all relevant empirical studies, this field is expanding exponentially making it difficult to be completely inclusive. Our bias favoring only empirically based studies demonstrating clear outcomes may have inadvertently excluded some articles for inclusion. Finally, two additional empirical evaluations with adequate outcomes were located yet they were not published in peer-reviewed journals. This is noteworthy as there may be some additional work underway and not captured here. Despite these limitations, this review offers guidance for future research and evaluation. In particular, we have demonstrated a lack of outcome-based work in this area and call for evaluation in this domain to begin to further our understanding.

\section{Conclusion}

Despite the exponential growth in published research in the domain of open-learning resources, the empirical, evaluative body of work is thin. Perhaps, this is due to the limits in funding and/or expertise in evaluation. Indeed, there is huge potential for medical and health care professions educators to capitalize on these rich open data sets in a variety of contexts to support a range of outcomes expected to be achieved by medical graduates. The use of open data from social media channels in health care research and medical education is still in its infancy. ${ }^{25}$ For practice, we hope that this study will serve to stimulate and subsequently generate research and evaluation in the area of social media use in medical education.

Social media and the term web 2.0 technologies have opened up opportunities for Medicine and, in particular, the emergence of the construct Medicine 2.0 or a computerization of medical services. Medicine 2.0 is related primarily to patients and their interaction with health care professionals (e.g., physicians, specialists, and other clinicians). In practical terms, Medicine 2.0 is redefining the doctor-patient relationship. This is an innovative shift in medicine and worthy of rigorous research and evaluation to better understand functionality and evaluate patient outcomes.

\section{Disclosure}

The authors report no conflicts of interest in this work. 


\section{References}

1. Carroll CL, Bruno K, vonTschudi M. Social media and free open access medical education: the future of medical and nursing education? Am J Crit Care. 2016;25(1):93-96.

2. Jalali A, Wood TJ. Tweeting during conferences: education or just another distraction? Med Educ. 2013;47(11):1119-1145.

3. Jalali A, Sherbino J, Frank F, Sutherland S. Social media and medical education: exploring the potential of Twitter as a learning tool. Int Rev Psychiatry. 2015;27(2):140-146.

4. Cheston CC, Flickinger TE, Chisolm MS. Social media use in medical education: a systematic review. Acad Med. 2013;88(6):893-901.

5. Roy D, Taylor J, Cheston CC, Flickinger TE, Chisolm MS. Social media: portrait of an emerging tool in medical education. Acad Psychiatry. 2016;40(1):136-140.

6. Sterling MR, Leung P, Wright D, Bishop TF. The use of social media in graduate medical education (GME): a systematic review. Acad Med, Epub 2017 Feb 21.

7. Pant S, Deshmukh A, Murugiah K, Kumar G, Sachdeva R, Mehta JL. Assessing the credibility of the "YouTube approach" to health information on acute myocardial infarction. Clin Cardiol. 2012;35(5):281-285.

8. Cousins JB, Goh SC, Clark S, Lee LE. Integrating evaluative inquiry into the organizational culture: a review and synthesis of the knowledge base. Can J Program Eval. 2004;19(2):99-141.

9. Punch KF. Introduction to research methods in education. 2009. Thousand Oaks: Sage.

10. McGowan BS, Wasko M, Vartabedian BS, Miller RS, Freiherr DD, Abdolrasulnia M. Understanding the factors that influence the adoption and meaningful use of social media by physicians to share medical information. J Med Internet Res. 2012;14(5):e117.

11. Hughes B, Joshi I, Wareham J. Health 2.0 and Medicine 2.0: tensions and controversies in the field. J Med Internet Res. 2008;10(3):e23.

12. Alotaibi NM, Samuel N, Wang J, et al. The use of social media communications in brain aneurysms and subarachnoid hemorrhage: a mixed-method analysis. World Neurosurg. 2017;98:456-462.

13. Azer S. Can "YouTube" help students in learning surface anatomy? Surg Radiol Anat. 2012;34(5):465-468.
14. Camm CF, Sunderland N, Camm JA. A quality assessment of cardiac auscultation material on YouTube. Clin Cardiol. 2013;36(2):77-81.

15. Raikos A, Waidyasekara P. How useful is YouTube in learning heart anatomy? Anat Sci Edu. 2014;7(1):12-18.

16. Whittaker AL, Howarth GS, Lymn KA. Evaluation of Facebook( ) to create an online learning community in an undergraduate animal science class. Educ Media Int. 2014;51(2):135-145.

17. Mahoney MC, Erwin DO, Widman C, et al. Formative evaluation of a practice-based smoking cessation program for diverse populations. Health Educ Behav. 2014;41(2):186-196.

18. Pearson D, Bond MC, Kegg J, et al. Evaluation of social media use by emergency medicine residents and faculty. West J Emerg Med. 2015;16(5):713-720.

19. Strausburg MB, Djuricich AM, Carlos WG, Bosslet GT. The influence of the residency application process on the online social networking behavior of medical students: a single institutional study. Acad Med. 2013;88(11):1707-1712.

20. Thalluri J, Penman J. Social media for learning and teaching undergraduate sciences: good practice guidelines from intervention. Electron $J$ e-Learn. 2015;13(6):455-465.

21. Wang AT, Sandhu NP, Wittich CM, Mandrekar JN, Beckman TJ. Using social media to improve continuing medical education: a survey of course participants. Mayo Clin Proc. 2012;87(12):1162-1170.

22. Hennessy CM, Kirkpatrick E, Smith CF, Border S. Social media and anatomy education: using Twitter to enhance the student learning experience in anatomy. Anat Sci Educ. 2016;9(6):505-515.

23. Walton JM, White J, Ross S. What's on YOUR Facebook profile? Evaluation of an educational intervention to promote appropriate use of privacy settings by medical students on social networking sites. Med Educ Online. 2015;20:28708.

24. YouTube. 2012. Get more into learning. YouTube, LLC., San Bruno, CA. Available from: http://www.youtube.com/t/education. Accessed February 27, 2017.

25. Lafferty NT, Manca A. Perspectives on social media in and as research: a synthetic review. Int Rev Psychiatry. 2015;27(2):85-96.
Advances in Medical Education and Practice

\section{Publish your work in this journal}

Advances in Medical Education and Practice is an international, peerreviewed, open access journal that aims to present and publish research on Medical Education covering medical, dental, nursing and allied health care professional education. The journal covers undergraduate education, postgraduate training and continuing medical education

\section{Dovepress}

including emerging trends and innovative models linking education, research, and health care services. The manuscript management system is completely online and includes a very quick and fair peer-review system. Visit http://www.dovepress.com/testimonials.php to read real quotes from published authors. 